\title{
UNA BREVE SEMBLANZA AUTOBIOGRÁFICA (CORREO DE BOHUMIL BAĎURA CON SIGFRIDO VÁZQUEZ CIENFUEGOS)
}

\section{Introducción ${ }^{1}$}

Al profesor Bad'ura debí conocerlo hacia el año 2009 por mediación de Josef Opatrný. Durante mi estancia en Praga como profesor de la VŠE (Universidad Económica de Praga) el curso 2008/2009 acudía habitualmente al Centro de Estudios Ibero-Americanos de la Universidad Carolina de Praga a visitar al profesor Opatrný. En un día del que he perdido memoria de la fecha llegó al despacho un hombre menudo, encogido por el peso de los años, de modos tranquilos, con un acento checo pronunciado pero con un español pausado y claro. Me llamó la atención su cariñosa amabilidad y la modestia en el modo de dirigirse a mí, siempre educado y muy respetuoso, ese trato cortés y casi ceremonioso que dispensaba a todo el mundo. Valga como anécdota su costumbre de enviar cartas escritas a máquina agradeciendo las puntuales colaboraciones con un lenguaje y tratamiento propio del tiempo pasado que habitualmente trabajaba.

Durante los meses que estuve en Praga en aquella ocasión nos encontramos numerosas veces y hablamos de su viejo proyecto sobre El Caney, olvidado entre sus papeles. Recuerdo como Josef y yo le animamos a que terminara aquel trabajo suyo de años, iniciado en sus estancias en Cuba en los años sesenta y que había tenido que

1 Nota del editor: El siguiente texto es un correo personal que el profesor Bohumil Bad'ura me envió como respuesta a una serie de conversaciones tenidas con respecto al estudio que estoy desarrollando sobre la historiografía iberoamericanista checoslovaca en tiempos de la Guerra Fría. El correo fue recibido el 19 de junio de 2014, pocos meses antes de su fallecimiento (21 de septiembre de 2014). Tanto Bohumil Bad’ura, como su esposa Anežka Bad'urová acordaron publicar los datos personales de Bohumil Bad'ura junto con el presente texto. interrumpir. Una de mis mayores alegrías en Praga fue saber que finalmente terminó su viejo proyecto en $2013 .^{2}$

Mi colaboración con Badura siempre fue puntual, sobre todo revisando sus textos sobre el dilema que en 1618 tenía Felipe III sobre si centrarse en la situación en Bohemia o plantear una campaña en Argel. ${ }^{3}$ Sus textos siempre eran densos, cargados de información y con un profundo conocimiento de las circunstancias históricas. También estuve ayudándole en la edición en español de los documentos de los desposorios de Felipe II con Ana de Austria en Praga por poderes en 1580, que me temo han quedado inéditos.

Guardadas en mi memoria están las dos oportunidades que tuve de oírlo dar una conferencia. En una ocasión en los simposios que todos los martes del curso desde 1967 se celebran en el Centro de Estudios Ibero-Americanos. Sin embargo de la que guardo un recuerdo con mayor emoción fue la última, en la presentación en el Instituto Cervantes el 2 de abril de 2014 de un libro de Pavel Marek. ${ }^{4}$ Aquel día tuve la suerte de compartir escena nada menos que con Bohumil Badura, Josef Opatrný y el propio Pavel Marek. Recuerdo como llegó Bad'ura muy cansado, golpeado claramente por la enfermedad (con su "mala salud de hierro"

2 Bohumil Bad'ura, Páginas de la historia del pueblo del Caney, Praga 2013. Merece una atenta lectura el capítulo de Agradecimientos y las Palabras de introducción, por lo descriptivo que resultan en cuanto a las vicisitudes vitales para completar dicho trabajo.

3 Fue publicado en dos partes. Bohumil Bad'ura, “AArgel o Bohemia? El dilema español (16181619)", Ibero-Americana Pragensia, $1^{\mathrm{a}}$ parte: XLIV/2010, Praga 2016, pp. 43-65; $2^{\mathrm{a}}$ parte, XLV/1/2010, Praga 2017, pp. 27-71.

4 Pavel Marek, La embajada española en la corte imperial (1558-1641). Figuras de los embajadores y estrategias clientelares, Praga 2013. 
como le gustaba decir), pero aún así no quiso perder la oportunidad de acompañar a un joven profesor como Marek, al que sentía como magnífico continuador de la tradición historiográfica hispanística checa de la que él había formado parte. La ponencia de Bad'ura fue un epílogo casi teatral a su vida como investigador. Aquel día empezó con cierto brío y fuerza su exposición, sin embargo, con el paso de los minutos sus energías se fueron agotando y sus últimas frases se fueron volviendo ininteligibles para la mayoría de nosotros. Creo que todos los presentes fuimos conscientes de que difícilmente volveríamos a ver al viejo profesor otra vez dando una lección magistral como aque1la. Por desgracia no nos equivocábamos.

En mi caso aún mantuve cierto contacto por correo electrónico y gracias a la intercesión de su esposa Anežka Bad'urová, que contestaba los correos transcribiendo sus palabras para mí. El profesor sabía del proyecto que estaba llevando a cabo sobre el estudio de la historiografía iberoamericanista checoslovaca y mi deseo de entrevistarle. Dado el declive imparable de su mala salud me obsequió con un resumen sucinto de su vida por escrito, con un breve sumario de lo que él creía debía recordarse de sus años al servicio de la investigación en Checoslovaquia primero y en República Checa más tarde. El siguiente texto es el que el profesor Bohumil Bad'ura me envió. Dada su naturaleza testimonial única consideré que no debía quedar como simple material para mi trabajo y que debía ser compartido. Sirva como humilde homenaje personal a una persona sabia y entrañable. ${ }^{5}$

\section{por Sigfrido Vázquez Cienfuegos (Cáceres) (Escrito en español por el autor)}

\section{Estimado y querido colega:}

Le ruego a $\mathrm{Vd}$. que me perdone la tardanza en el envío de las siguientes páginas. Ya es para mí imposible cumplir con alguna promesa porque mi salud o, mejor dicho, mi enfermedad no me permite tener unos planes fijos ni siquiera para el día siguiente. Pero debido a que el proyecto de Vd. exigirá todavía más tiempo, supongo que mi tardanza

5 Al final del texto se acompañará con una bibliografía que fue facilitada por Anežka Bad'urová. Por razones de extensión no se ha incluido la sección de reseñas. no tenga consecuencias desagradables. De mayor importancia es que Vd. probablemente no esté contento con el contenido de lo que le estoy mandando a pesar de que traté de que por lo menos algo de estas líneas pudiera servirle a Vd. Sin embargo, no he conseguido separar lo relativo a mi trabajo de lo que se refería a mi vida, la cual probablemente no le interesará, pero lo uno y lo otro está más o menos enlazado. A Vd., naturalmente, le importa sobre todo llegar a saber el desarrollo de la historiografía checa tocante a la América Latina, escrita en español como resultado de la investigación realizada por los historiadores checos en los archivos y bibliotecas latinoamericanos, especialmente durante el tiempo relativamente poco propicio al progreso de los estudios historiográficos checos o checoslovacos concernientes al pasado de los países de aquella parte del mundo. Así yo entiendo lo que sale de las palabras de Vd. al informarme de su interesantísimo y útil proyecto.

Reaccionando a la carta de Vd., no puedo, en el primer lugar, dejar de advertir que para el estudio de algunos temas relativos a la historia de América Latina y España existen fuentes también en nuestros archivos y que incluso no es posible pasarse sin ellas, especialmente si se trata de una investigación de las relaciones entre los países checos y el mundo iberoamericano. Durante el tiempo de la Guerra Fría, cuando el contacto directo de los historiadores checos con la América Latina y España era limitado, la búsqueda y el aprovechamiento de tal documentación adquiría extraordinaria importancia. En mi propio trabajo esto se refiere sobre todo a la investigación de la exportación del vidrio checo a México, a los intereses de las fábricas de armamento checas y a la política de nuestro Estado en la Guerra de Gran Chaco entre Bolivia y Paraguay y a la emigración de las personas de Bohemia y Moravia a Argentina y Brasil. Sucedió también que algún tema, para que su investigación pudiera ser llevada a cabo, requería que ésta fuera complementada con la emprendida en los archivos extranjeros. Solamente de esta manera pude escribir la "Biografía de la hacienda de San Nicolás de Ulapa" en la región mexicana del Mezquital, estudio que halló cierto eco positivo entre varios historiadores extranjeros.

6 Bohumil BAĎURA, "Biografía de la hacienda de San Nicolás de Ulapa", Ibero-Americana Pragensia IV, Praga 1970, pp. 75-111. 
Sin embargo, lo más importante para cualquier iberoamericanista es la posibilidad de trabajar en los archivos y bibliotecas de Latinoamérica. A mí se me ofreció esta suerte, soñada pero no esperada, como una feliz o, mejor dicho, milagrosa consecuencia del encuentro con el profesor universitario mexicano Raúl Cordero Amador y su esposa, a los cuales acompañé como guía y traductor durante el primer simposio internacional de comeniólogos (1956) en Praga. Desperté en ellos, no sabiendo explicármelo, tal simpatía o cariño que me invitaron para pasar seis meses en su casa. Lo consideré como una pasajera cortesía, pero ellos lo pensaban seriamente. Repitieron su invitación por escrito, dirigiéndose en este asunto también a nuestro Ministerio de Asuntos Exteriores. Pero sin la perspectiva del éxito, ya que el permiso para un viaje particular a un estado capitalista era entonces algo extraordinario, quimérico, sobre todo tratándose de una persona que no era miembro del Partido Comunista. No obstante, parece que en el cielo gocé (también sin saber explicármelo) del favor del mismo Dios o de algún poderoso intercesor, puesto que después de terminar mis estudios universitarios apareció una serie de otros milagros. Después de superar ciertos problemas políticos obtuve un empleo en la ČTK (Agencia Checoslovaca de Noticias), donde, al parecer contentos con mi trabajo, después de haber sido informados de la invitación por parte del profesor Cordero Amador y su esposa, la dirección e incluso, lo que más me sorprendió, el comité del Partido Comunista de la Agencia, decidieron ayudarme, recomendando mi viaje al departamento de prensa del ÚV KSČ (Comité Central del Partido Comunista), que dio su decisivo consentimiento. Y para el colmo de esta incomprensible generosidad, la Agencia resolvió pagarme el viaje a México, con la única obligación para mí de enviarle noticias sobre la actividad de la delegación checoslovaca durante la celebración del aniversario del comienzo, hace 150 años, de la Guerra de Independencia.

Gracias a todas estas felices circunstancias originadas por la inmensa amabilidad de mis anfitriones, "mis padres mexicanos", como los 1lamaba, pude vivir en México desde septiembre de 1960 hasta el marzo de 1961, dedicándome a la investigación de las fuentes históricas mexicanas. El principal lugar de mi trabajo era el Archivo General de la Nación. Después del cierre de la sala de investigación me solía trasladar por algunas horas a la Biblioteca Nacional. Ya antes de empezar a trabajar en el Archivo General de la Nación estuve decidido orientar mi investigación hacia algún problema de la posesión de la tierra, teniendo, sobre la base de mis lecturas, cierta idea de su importancia, e inspirado sobre todo por la excelente obra del historiador francés F. Chevalier, La formation des grands domaines au Mexique. Terre et société au XVI-XVII siècles, (Paris, 1952). Empecé mi labor mirando el contenido del ramo (fondo) de Tierras y lo que más llamó mi interés como tema que merecería mayor aclaración eran las composiciones de tierras en Nueva España. Al estudio de la documentación tocante a ellas dediqué mi principal atención. Debido a que las composiciones de tierras consistieron en el cumplimiento de varios aspectos o condiciones, su conocimiento requería ampliar la base de mi investigación. Aunque la principal fuente de los informes era el fondo de Tierras y Tierras-traslados, se necesitaba examinar también otros ramos del archivo, sobre todo Mercedes, Reales Cédulas, Reales Cédulas-copias y Bandos. Además se mostró, como llegué a enterarme después de cuatro años, cuando tuve por primera vez la oportunidad de venir a Sevilla asistiendo al XXXVI Congreso Internacional de Americanistas, que los importantes documentos para el estudio de las composiciones en Nueva España se encontraban también fuera de México, en el Archivo General de Indias, especialmente en el fondo de la Audiencia de México.

En 1962 ingresé en el Departamento de América Latina, fundado en el mismo año en el Instituto de Historia de la Academia Checoslovaca de Ciencias. Su fundación correspondió al cambio sustancial en el interés por esta parte del mundo, suscitado por la revolución cubana. Con ella surgió un extraordinario desarrollo de las multilaterales relaciones entre Checoslovaquia y Cuba, entre ellas también las concernientes a varios campos de la ciencia. La colaboración entre las Academias de ambos países creó las posibilidades para el intercambio de sus trabajadores, lo que en mi caso significó que en la primavera de 1965 fui enviado a La Habana para llegar a conocer las instituciones de mayor importancia para la historia de Cuba y dedicarme allí a la investigación. Pronto llegué al conocimiento de que las instituciones más importantes para mi labor serían el Archivo Nacional y la Biblioteca Nacional. En el Archivo Nacional encontré gran comprensión por parte de su director, el eminente historiador Julio Le Riverend Brusone, quien me permitió trabajar allí sin 
mirar el horario oficial, pudiendo así aprovechar aun las noches. ${ }^{7}$ En la Biblioteca Nacional me servían sobre todo las publicaciones guardadas en el Departamento de Colección Cubana, cuyo asesor científico Juan Pérez de la Riva, historiador y geógrafo francés radicado en la isla, me brindó toda la ayuda que yo necesitaba, honrándome además también con su amistad. Al principio pensé en concentrar mi investigación a la inmigración alemana en Cuba, contando con la posibilidad de poder continuar en ella, después de mi regreso, en los archivos alemanes. Pero al tratar de obtener la idea de la documentación existente en el Archivo Nacional, me di cuenta de que las inmigraciones extranjeras a Cuba tenían estrecha relación con la problemática mucho más vasta, con el esfuerzo de aumentar el número de los blancos, sobrepasado por el de la gente de color. Este desequilibrio provocaba inquietud y miedo entre la población blanca, particularmente en vista de la evolución en la vecina isla Española. La noción de que se trataba de un conjunto de problemas no desdeñable para la historia de Cuba me llevó a la resolución de ensanchar mi propósito original elaborando un trabajo más exigente, con la finalidad de presentarlo como tesis para obtener la candidatura de ciencias (CSc.), lo que realicé bajo el título Problém „podpory růstu bílého obyvatelstva“ na Kubě v 1. polovině XIX. stol. (El problema del "fomento de población blanca" en Cuba en la primera mitad del siglo XIX) ${ }^{8}$ después de volver a Praga. Los fondos más importantes del Archivo Nacional en los cuales basaba mi investigación fueron el del Real Consulado y Junta de Fomento, el de Asuntos Políticos, Miscelánea (Libros), Gobierno Superior Civil, Intendencia General de Hacienda, Escribanía de Bienes de Difuntos, Reales Ordenes y Protocolos Notariales. De los de menor provecho para mi trabajo mencionaré por lo menos el de Miscelánea (Legajos), Tribunal de Comercio y Correspondencia de Capitanes Generales.

De gran valor fue para mí el fondo de Ultramarinos en el Archivo del Arzobispado de La Habana,

7 Nota del editor: El profesor contaba cómo le habilitaron un lugar para dormir dentro de la propia biblioteca.

8 Inédito. De esta monografía Bad'ura solamente publicó extractos. Aclaración hecha por Anežka Bad’urová, esposa del profesor Bad'ura. donde se encuentran los documentos relativos a los matrimonios de los inmigrantes, con muchos interesantes datos tocantes a los que contraían matrimonio, informando hasta de sus suertes antes de venir a la isla. Los datos presentados por ellos tuvieron que ser confirmados por los testigos, que ofrecían noticias también de su propia vida antes y después de su llegada a Cuba.

La necesidad de no limitarme solamente a la documentación que había en La Habana para la problemática estudiada, me llevó, tomando en consideración la escasez del tiempo, a ver por lo menos lo que se encontraba para ella en Santiago de Cuba, sede del Archivo Histórico Regional, ubicado entonces en el recinto de la Universidad de Oriente. Allí, después de enterarme de los fondos que podrían interesarme, dediqué entonces la mayor atención a los Protocolos Notariales, verdadera mina para los informes económicos y demográficos. En el tiempo tan breve del que disponía, pudiendo quedarme en Santiago únicamente algunos días, logré apuntar sólo algo de lo que más me interesaba, pero mi dedicación a esta labor desde la mañana hasta la noche atrajo la atención del profesor Francisco Prat Puig, director de la Escuela de Historia de la Universidad, quien me llevó antes de mi regreso a algunos lugares cercanos a Santiago y durante nuestras charlas mostró el interés por mi investigación en Cuba y también por lo que estudié en Checoslovaquia. Para gran asombro mío, tras algunas semanas el profesor Prat envió dos de sus colegas a buscarme en el Archivo Nacional para ofrecerme la enseñanza de la asignatura "Técnica de la investigación histórica". Con este ofrecimiento y solicitud se dirigió asimismo a la dirección de la Academia de Ciencias de Cuba, la cual gestionó su aprobación por la Academia Checoslovaca, y ésta por el Instituto de Historia que me empleaba. Así que pude prolongar mi estancia en Cuba hasta la mitad del año de 1967, es decir, por dos años escolares, consagrándome a la enseñanza, preparación de las clases e investigación realizada principalmente en el Archivo Histórico Regional y en el Archivo Municipal. Allí traté de buscar nuevos informes para aumentar los conocimientos adquiridos en La Habana, pero sin pasar por alto lo que encontraba, entonces más bien casualmente, para el tema al que pensaba dedicarme en el futuro - la historia de San Luis de los Caneyes (abreviadamente del Caney), el pueblo de indios que mantuvo oficialmente este estatuto desde la segunda mitad del siglo XVI hasta los años 
cuarenta del siglo XIX. Esta larga duración del "pueblo de indios" en el país donde la mayor parte de la población aborigen desapareció ya durante el siglo XVI y los restos de ella necesariamente tuvieron que ir perdiendo su importancia y su carácter indígena, despertó en mi mente la decisión y el deseo de seguir detenidamente, en tanto que lo permitieran las fuentes conservadas, su historia para presentarla en forma de libro escrito en español. Estuve convencido de poder realizarlo, sabiendo del profesor Prat que la Universidad tenía el propósito de invitarme para otros dos años escolares, lo que sin duda me ofrecía la oportunidad de familiarizarme con todos los documentos relevantes concernientes a este pueblo. Pero cuando ya parecía que de parte de las autoridades checoslovacas no existía ningún obstáculo para mi vuelta a la Universidad, se mostró todavía la necesidad de la sanción de mi viaje por una comisión del Comité Regional del Partido Comunista. Aparentemente se trató de una pura formalidad, mas debido a la envidia o tontería (o a la combinación de ambas de estas cosas) de la persona más influyente de la comisión, hombre de muy problemático carácter, la comisión rechazó concederme el permiso. En el tiempo de los nefastos cambios a causa de la ocupación del país por el ejército de Pacto de Varsovia y del ambiente de inseguridad que empezó a reinar en la sociedad, los miembros de la comisión tenían miedo a intervenir en mi favor contra la voluntad de su dañino pero influente colega. De este modo quedaron reducidos a nada todos mis planes relacionados con mi regreso a la Universidad tocantes a la enseñanza y también a la investigación. Con esto, por descontado, perdieron también sentido mis viajes a varios lugares de la Provincia de Oriente (Holguín, Manzanillo, Bayamo, Victoria de las Tuna, Baracoa, Guantánamo, Banes, Gibara, Mayarí, Antilla y Puerto Príncipe), emprendidas con el fin de averiguar en qué estado se encontraban los archivos existentes allí (los municipales, los de las notarías, los parroquiales, etc.), para poder más tarde orientar y ayudar a los estudiantes a escoger un tema viable para la tesina. ${ }^{9}$

9 Cuando volvió de Cuba en el 67 trabajó sobre su disertación. En 1973 pidió permiso para volver a Cuba y obtuvo todos menos el del comité del Partido Comunista Checoslovaco, sin el cual fue imposible realizar el viaje. Aclaración hecha por Anežka Bad’urová.
Mi primera estancia en la isla (1965-1967) me trajo una oportunidad la cual no esperaba porque al ser enviado a La Habana ni en los primeros meses de mi permanencia allí se me hubiese ocurrido pensar en algo tan extraordinario y hasta imposible. No me vino a la mente la hipótesis del aprovechamiento de la estancia en Cuba para el viaje a México. A quien se le ocurrió tal posibilidad fue mis padres mexicanos. Al recibir el informe de mi arribo a Cuba, la cual mantenía con México una comunicación regular aérea, me mandaron la invitación para pasar con ellos por lo menos el fin del año. Entonces me enteré que con la moneda cubana era posible pagar el boleto. Sin esto no me atrevería a abusar de la nueva generosidad de mis anfitriones. Los Cordero Amador, debido a sus excelentes relaciones, incluso en el Ministerio del interior, lograron superar el mayor obstáculo para el viaje a México - la obtención del visado para mí. Es que en aquel tiempo el gobierno mexicano no estaba inclinado a otorgar el visado a los extranjeros del campo "socialista" que trabajaban en Cuba. Antes de la Navidad del año de 1965 ya había estado anteriormente en la capital mexicana, donde quedé casi hasta la mitad de enero. ${ }^{10}$ Además del placer que me daba el contacto diario con las personas queridas, la vuelta a México, así como la que pude efectuar en el siguiente año, me importaba mucho desde el punto de vista laboral. Ya en el año de 1961 me había dado cuenta de que entre los documentos consultados en el Archivo General de la Nación había igualmente los que se referían a la hacienda San Nicolás de Ulapa, objeto de mi investigación basada en las fuentes que se hallaban en un archivo checo - el de Žitenice (que ya no existe), sucursal del Archivo Regional de Estado de Litoměrice. Éste pasó como uno de los fondos del archivo familiar del príncipe Max Egon von Hohenlohe-Langenburg, que contenía también un conjunto de papeles referentes a su propiedad rústica en México. Max Egon estaba casado con Piedad de Iturbe, copropietaria de estos bienes. Los documentos que se hallan en el archivo familiar de Hohenlohe permiten seguir gran parte de la historia de la mencionada hacienda, muy interesante

10 Según Anežka Badurová, no estuvo en la Navidad del año 65 en México, sino entre agosto y el otoño, luego volvió a Cuba, donde le esperaba ella. Ella cree recordar que fue la Navidad de 1966 la que pasó en México. 
desde varios puntos de vista. Sin embargo, tan sólo reuniendo los resultados de la investigación hecha en Bohemia y los de la que realicé durante mis dos escapadas de Cuba a México en los años 1966 y 1967, siempre en dos semanas del nuevo año, fue posible llegar a una visión tan completa como la que pude presentar en mi estudio, dividido en los capítulos: "La hacienda y sus propietarios", "Disputas de la tierra con los vecinos", "La mano de obra" y "El ocaso de la hacienda". Además de los archivos de la capital mexicana me sirvió, especialmente para el último capítulo, el Archivo Municipal de Tepetango, donde encontré unos documentos importantes también para la historia de Ulapa. Ésta, al principio, en el siglo XVI, pueblo indígena, cuya tierra fue sustancialmente aumentada con las adquisiciones (usurpación, compra, herencia) hechas en los siguientes siglos, formando la hacienda destinada sobre todo a la cría de ganado. Volvió a tener como consecuencia de la revolución su antiguo carácter de pueblo aun cuando sus actuales términos seguramente no concuerdan con los que tenía en el siglo XVI. Así terminó el interesante e imprevisto ciclo del cual pienso que valía la pena de ser estudiado. Sin embargo, lo que asimismo me importó, y muchísimo, era la oportunidad de ver con mis propios ojos los lugares que conocía exclusivamente de los papeles. Mi amigo, el renombrado historiador mexicano Ernesto de la Torre Villar, me llevó en su coche a hacer una visita a Mezquital y, naturalmente, al pueblo de Ulapa. ${ }^{11}$ Quedé impresionado por su desarrollo y también por la vista de lo que permanecía de los edificios de la hacienda. Algunas fotos que hice de estas ruinas, donde todavía estaba en sus funciones originales la capilla, acompañan el estudio publicado en el anuario Ibero-Americana Pragensia IV, 1970, pp. 75-111. Mi último viaje a México se efectuó en marzo de 1991 pero solamente por una semana. El mérito de mi último encuentro con el país en el cual comenzó mi relación directa con las fuentes históricas latinoamericanas lo tiene el profesor Hanns-Albert Steger, presidente del Consejo Europeo de Investigaciones Sociales sobre América Latina (CEISAL), gracias a cuya amabilidad

11 Desde su primera estancia en México también trabó contactos además de con Ernesto de la Torre Villar, con María Elenas Bribiesca Sumano y Héctor Ochotorena. Aclaración hecha por Anežka Bad’urová. pude participar en las jornadas "Nueva Europa y México", organizadas en Guadalajara por el Colegio de Jalisco. El ciclo de conferencias continuó después en la capital mexicana. Con mucho gusto sacrifiqué las horas reservadas a la comida y descanso, visitando el Archivo General de la Nación que ya poseía su propio edificio para ver en el fondo de Inquisición los documentos salidos del juicio contra Andrés Morav [sic], nacido según su declaración en la ciudad morava de Brno. Lo que sabía sólo de la obra de Toribio Medina pude ahora mirarlo con mis propios ojos y estudiarlo después en mi patria en el microfilm que me hicieron en el archivo, cumpliendo pronto con mi solicitud. Las fotos hechas de la "película" las empleé en una de mis clases en el Centro de Estudios Ibero-Americanos para que los alumnos pudieran seguir este asunto de los documentos y se dieran cuenta de los problemas paleográficos que en ellos aparecían.

A Cuba no pude volver hasta después de 29 años (en 1996), ni más ni menos que para tres meses enteros. Los aproveché para regresar a mi idea de estudiar el pasado del Caney, dedicando a ello todo mi tiempo libre. Sin embargo, era evidente que sería imposible enterarme de toda la documentación necesaria e investigar a fondo todo el material encontrado. La mayor parte de mi segunda estancia cubana la pasé en Santiago, trabajando allí ante todo en el Archivo Histórico Provincial, en el Archivo Histórico Regional y en el Archivo Municipal. Más tarde, como me informó la profesora Olga Portuondo, el Archivo Histórico Regional y el Archivo Municipal pasaron a formar parte del Archivo Histórico Provincial. En éste me servía para mi investigación sobre todo el fondo del Juzgado de primera instancia, especialmente los legajos de Testamentos y los Protocolos Notariales del Caney, provenientes de los años cuarenta y cincuenta del siglo XIX. Los anteriores y posteriores no los hallé. Pero los informes referentes al Caney se encuentran asimismo en las notarías existentes en el Archivo Histórico Regional. De las fuentes eclesiásticas la mayor cantidad de importantes datos los contenían los libros parroquiales del Caney que empezaron ser llevados por los curas párrocos desde el año de 1690. En el tiempo de mi segunda estancia en Cuba estaban depositados en la Iglesia de la Sagrada Familia en Vista Alegre. Para examinarlos minuciosamente se necesitaba mucho más tiempo que del cual disponía, pero incluso esta circunstancia era menos sensible gracias a la comprensión de las monjas encargadas también de 
cuidar la Iglesia, que me permitieron venir allí en cualquier día y hora. En Santiago trabajé también en el Archivo del Arzobispado y en el Museo de la Catedral.

Mi estancia en la Isla terminó en La Habana, buscando y examinando la documentación sobre El Caney en el Archivo Nacional. Éste tiene para la historia de aquel pueblo una enorme importancia, porque sus fondos contienen los documentos surgidos de la actitud de los organismos oficiales que tuvieron que ocuparse de variados aspectos de la historia del pueblo. A causa de la escasez de tiempo no pocos documentos solamente pasaron por mis manos, teniendo que contentarme con apreciar su valor y separarlos en un lugar del armario por si acaso pudiera conseguirse su microfilmación. En otros casos pude únicamente apuntar, con semejante esperanza, las signaturas, para después solicitar, pagando el respectivo importe, las copias, como solía hacerlo, sin ningún problema, en los archivos europeos. La separación en el armario de la sala de investigación de los documentos revisados (más de dos mil páginas) tuvo éxito, puesto que mi amiga, la doctora Isabel Fernández Santana, entonces vicedirectora del Archivo Nacional, logró su reproducción en microfilm que me envió a Praga. Sin embargo, la dificultad con la vista y después otras obligaciones no me permitieron aprovechar este material y ya dejaría de pensar en hacerlo, descorazonado asimismo por la absoluta desgana de la dirección del Archivo Nacional de cumplir con la repetida solicitud de dejar confeccionarme las copias de los documentos, cuyas signaturas les enviaba, a pesar de mi ofrecimiento de pagar de antemano en dólares por este servicio. Pero viendo que ya se aproxima el fin de mi vida y dándome lástima la pérdida de tanto tiempo y trabajo, leí y transcribí o apunté todo lo microfilmado y, alentado y ayudado por mis amigos cubanos, escribí, si no la historia, como era mi propósito original, a lo menos el libro titulado Páginas de la historia del pueblo del Caney, salido a la luz en agosto de 2013. ${ }^{12}$ Con este libro, por supuesto imperfecto, me despedí de mi labor tocante a los temas cubanos y latinoamericanos.

Éstos, sin embargo, no eran el único objeto de mi investigación iberoamericanista. Gran parte de ella se refería a la historia de España y sus

12 Bohumil BAĎURA, Páginas de la historia del pueblo del Caney, Praga 2013. relaciones con los países checos. Aun durante el tiempo de la Guerra Fría podía trabajar en esta problemática, basándome en la riqueza de nuestros archivos, donde no faltan las fuentes relativas a la historia de España y a los vínculos de distinto género con el Reino de Bohemia. El informe tocante a ellas, pero muy escueto y limitado temporalmente presenté en el folleto, elaborado con ocasión del XVII Congreso Internacional de Ciencias Históricas en Madrid (1990), bajo el título Hispanica de los siglos XVI y XVII en los archivos de Bohemia y Moravia. ${ }^{13}$ Aproveché mi asistencia a este Congreso para prolongar mi estancia en España, donde entonces quedé tres semanas investigando en la Biblioteca Nacional y en la biblioteca de la Real Academia de la Historia. Después, habiendo obtenido en los años 1992 y 2000 la beca de tres meses del Ministerio de Asuntos Exteriores español, pude ampliar sustancialmente mi labor, trabajando en varias otras instituciones: en el Archivo Histórico Nacional (Madrid), Archivo General de Simancas, Archivo General de Indias (Sevilla), Archivo de la Universidad de Salamanca, Archivo de carmelitas descalzas de "Santa María del Corpus Christi" (Alcalá de Henares), Archivo de la Real Chancillería de Valladolid y Archivo de la Corona de Aragón (Barcelona). Desgraciadamente gran parte de mi investigación estaba orientada a las fuentes que debían servir juntamente con las provenientes de otros archivos extranjeros (principalmente del Haus-, Hof, - und Staatsarchiv de Viena) y checos para preparar un libro sobre la política de los Habsburgos al principio de la Guerra de los Treinta Años. La obra debía resultar de mi colaboración con el profesor Polišenský en cuya mente nació esta idea. No obstante de muchos años durante los cuales hemos reunido una vastísima base para ella, la obra quedó en mero propósito nunca realizado. El profesor Polišenský, nuestro excelente y probablemente el mejor especialista en la historia general, estaba absorbido por el trabajo tocante a una serie de otros importantes temas que le distraían de la labor en el pensado común libro y yo, después de su fallecimiento en 2001, no encontré la

13 Bohumil BAĎURA, Hispanica de los siglos XVI y XVII en los archivos de Bohemia y Moravia, Praga 1990. También publicado en Ibero-Americana Pragensia XXVI, Praga 1992, pp. 195-215. 
energía y capacidad para emprenderla solo, tanto más por cuanto tendría que tomar en consideración la aparición en 2006 del libro de Josef Forbelský, Španělé, Říše a Čechy v l6. a l7. století (Los españoles, el Imperio y Bohemia en los siglos XVI y XVII), ${ }^{14}$ ya que trataba, a pesar de que parte de una base más estrecha de la que disponíamos nosotros, también de los problemas que debían ser objeto de nuestra obra. Así que gran parte de los resultados de mi investigación, especialmente de la realizada en el Archivo General de Simancas, en el Archivo Histórico Nacional de Madrid y en el de Viena, quedó en realidad malograda. De la hecha en Simancas elaboré solamente un estudio, pensado como uno de los subcapítulos de nuestro planeado libro. En él me ocupé de la influencia que tuvo la Guerra de Bohemia para que el rey de España abandonara su soñado proyecto de la jornada contra Argel, por cuyo cumplimiento ya se hacían vastas preparaciones en España, Italia y los Países Bajos. El estudio fue publicado en checo (2002) y en dos números del anuario Ibero-Americana Pragensia (XLIV y XLV/1) que fue publicada a continuación su traducción española. ${ }^{15}$ Sin utilidad no quedó mi investigación en el Archivo de la Corona de Aragón, donde busqué en el fondo de Cancillería las fuentes relativas a los viajeros del Reino de Bohemia en la Época Medieval. El resultado de esta labor forma parte del estudio "Los contactos entre el reino de Bohemia y España en la Edad Media", publicado (2006) en el libro Los países checos y España. Dos estudios de las relaciones checo-españolas. ${ }^{16}$

[...]

Termino esta carta pidiendo la disculpa por los defectos gramaticales, estilísticos e igualmente por las faltas que quedaron dentro de algunas palabras, mas confieso que ya carezco de energía para volver a leer este texto.

Afectuosamente y deseándole a Vd. el éxito en la realización de tan interesante e importante proyecto, su colega y sincero amigo,

Bohumil Bad'ura

14 Josef FORBELSKÝ, Španělé, Říše a Čechy v l6. a l7. století, Praha 2006.

15 Nota del editor: véase la nota 3.

16 Bohumil BAĎURA, Los países checos y España: dos estudios de las relaciones checo-españolas, Praga 2006.

\section{BIBLIOGRAFÍA SELECTA}

\section{Monografías}

Hispanica de los siglos XVI y XVII en los archivos de Bohemia y Moravia. Publicado con ocasión del XVII Congreso Internacional de Ciencias Históricas en Madrid, Praga: Instituto de Historia de la Academia Checoslovaca de Ciencias, 1990, 34 pp.

Los países checos y España. Dos estudios de las relaciones checo-españolas (=Ibero-Americana Pragensia, Supplementum 16), trad. Pablo Chacón Gil - Miguel José Cuenca Drouhard, Praga: Editorial Karolinum 2007, 227 pp.

Páginas de la historia del pueblo del Caney (=Ibero-Americana Pragensia, Supplementum 30), Praga: Editorial Karolinum, 2013, 352 pp.

Španělsko-americká válka 1898. První mezinárodní válečný konflikt v epoše imperialismu, Praha: Academia, 1989, 279 pp.

\section{Coautoría en trabajos colectivos}

ABC světových dějin, Praha: Orbis, 1967, 1155, [15] pp. (cap. Věda a život)

Antonín Šnejdárek (ed.), B. Bad’ura-L. Suchánková - L. Neckářová - H. Rambousková (comp.),Bibliografie pracío LatinskéAmerice, Praha: Historický ústav ČSAV, 1963, 2 vols., 408 pp., 100 pp.

Dějiny Latinské Ameriky, Praha: Svoboda, 1979 (autoría pp. 89-213).

Diplomacie bez rukaviček, con Vít Janáček, Praha: Nakladatelství politické literatury 1962, 125, [16] pp., 1 il.

Documenta Bellum Tricenalle Illustrantia, tomo 2, Der Beginn des Dreissigjährige Krieges. Der Kampf um Böhmen. Quellen zur Geschichte des Böhmische Krieges (1618-1621), ed. Miroslav Toegel et al., Praha: Academia, 1972, 332 pp., il.

Documenta Bohemica Bellum Tricennale illustrantia, tomo 6, Der grosse Kampf um die Vormacht in Europa. Die Rolle Schwedens und Frankreichs. Quellen zur Geschichte des Dreissigjähriges Krieges 1635-1643, ed. B. Badura et al., Praha: Academia, 1978. 533 pp. 20 il.

\section{Estudios en revistas y actas}

"K problému španělské absolutní a „universální“ monarchie v 17. stol", Časopis Matice moravské 77/3-4, Brno: Matice moravská, 1958, pp. 375-385. 
"K současné španělské historiografii”, Československý časopis historický 6/1, Praha: Nakladatelství Československé akademie věd (en adelante sólo Nakladatelství ČSAV), 1958, pp. 146-148.

“Kuba bojující a vítězná”, Co vás zajímá 11/12, Praha: Státní nakladatelství pedagogické literatury (en adelante sólo SNPL), 1959, pp. 44-49.

"Zápas o Valtelinu a český odboj protihabsburský (1618-1620)", in: Sborník historický 7, Praha: Nakladatelství ČSAV, 1960, pp. 123-156.

/anónimamente/ "Diego Rivera o sobě", Latinská Amerika 2/9, Praha: Klub přátel Kuby, 1963, pp. 6-8.

"Poznámky o organizaci historického bádání v Mexiku", Československý časopis historický 11/1, Praha: Nakladatelství ČSAV 1963, pp. 86-94.

"První konference skupiny pro LA. (15. 1. 1963)", Věstník ČSAV 72/3, Praha: Nakladatelství ČSAV, 1963, pp. 379-381.

"První konference skupiny pro LA. (15. 1. 1963)", Československý časopis historický 11/3, Praha: Nakladatelství ČSAV, 1963, pp. 411-412.

"Plány na integraci indiánského obyvatelstva v Peru", Latinská Amerika 3, Praha: Klub přátel Kuby, 1964, pp. 22-25.

"Apuntes sobre los orígenes del comercio vidriero entre Bohemia y México (1787-1839)", Historica 9, Praha: Academia, 1964, pp. 69-134.

“Z pramenů k ruským objevným cestám v 2. pol. 18. století v mexickém archivním fondu", Československý časopis historický 11, Praha: Nakladatelství ČSAV, 1963, pp. 805-813.

"Několik informací o předpokladech a vývoji studia dějin Latinské Ameriky ve Španělsku", Československý časopis historický 13, Praha: Nakladatelství ČSAV, 1965, pp. 578-594.

“Agrární otázka a názory na ni v mexické revoluci 1910-1917', in: Sborník historický 14, Praha: Nakladatelství ČSAV, 1966, pp. 135-185.

"A propósito de Fundamentos de Historia", Revista de la Biblioteca Nacional „José Martí“ 2, La Habana 1967, pp. 5-24.

"Algunos Informes acerca de la Organización y las Condiciones de Investigación Histórica en Cuba", Ibero-Americana Pragensia 2, Praga: Editorial Karolinum, 1968, pp. 207-228.

"Biografía de la Hacienda de San Nicolás de Ulapa", Ibero-Americana Pragensia 4, Praga: Editorial Karolinum, 1970, pp. 75-111.
"La historia de Cuba durante el primer decenio socialista", Revista de la Biblioteca Nacional "José Marti”" ”, La Habana: Biblioteca Nacional de José Martí, 1970, pp. 3-34.

"Los Franceses en Santiago de Cuba a Mediados del Año de 1808", Ibero-Americana Pragensia 5, Praga: Editorial Karolinum, 1971, pp. 157-160.

"Některé aspekty španělského a britského kolonialismu v Americe v 16. a 17. stoletî", in: Sborník k problematice dějin imperialismu 2 , Praha: Ústav československých a světových dějin ČSAV, 1973, pp. 1-189.

"Emiliano Zapata a jeho role v mexické revoluci", Společenské vědy ve škole 31/7, Praha: Státní pedagogické nakladatelství, 1974-1975, pp. 197-200.

"Sobre la inmigración alemana en Cuba durante la primera mitad del siglo XIX", Ibero-Americana Pragensia 9/1975, Praga: Editorial Karolinum, 1976, pp. 71-105; en español, Ibero-Americana Pragensia 10, Praga: Editorial Karolinum, 1976, pp. 111-136.

"Z historie francouzské imigrace na Kubě počátkem 19. stoletî", in: Sborník historický 23, Praha: Nakladatelství ČSAV, 1975, pp. 169-199.

"Československé zbraně a diplomacie ve válce o Gran Chaco", in: Sborník historický 24, Praha: Nakladatelství ČSAV, 1976, pp. 137-185.

"Agrární tisk a španělská občanská válka", in: Sborník $k$ problematice dějin imperialismu 5 , Praha: Ústav československých a světových dějin ČSAV, 1978, pp. 381-396.

"Komposice půdy v Novém Španělsku v 17. a 18. stoletî", Hospodářské dějiny. Economic History 1, Praha: Historický ústav ČSAV, 1978, pp. 295-371.

“Z postoje českého pravicového tisku k španělské národně revoluční válce", in: Sborník k problematice dějin imperialismu 6, Praha: Ústav československých a světových dějin ČSAV, 1979, pp. 161-248.

"Los intereses de la burgesía checoslovaca en la guerra de Gran Chaco, $1^{\text {a }}$ parte", Ibero-Americana Pragensia 14/1980, Praga: Editorial Karolinum, 1984, pp. 169-201; 2 a parte, Ibero-Americana Pragensia 15/1981, Praga: Editorial Karolinum, 1985, pp. 161-192.

"La Ibero-Americanística y el Instituto de Historia Checoslovaca e Universal de la ACCh", con Libuše Neckářová, Ibero-Americana 
Pragensia 15/1981, Praga: Editorial Karolinum, 1985, p. 222.

"K historii prvních spolků českých a slovenských vystěhovalců v Argentině”, in: Sborník k problematice dějin imperialismu 11, Praha: Ústav československých a světových dějin ČSAV, 1981, pp. 279-332.

“Španělsko v letech 1970-1979”, in: Sborník k problematice dějin imperialismu 9, Praha: Ústav československých a světových dějin ČSAV, 1981, pp. 149-180.

"Poznámky ke vzniku fašismu ve Španělsku”, in: Sborník k problematice dějin imperialismu 13, Praha: Ústav československých a světových dějin ČSAV, 1982, pp. 247-275.

"Realizace výsledků španělsko-americké války", in: Sborník k problematice dějin imperialismu 15, Praha: Ústav československých a světových dějin ČSAV, 1983, pp. 53-62.

"Apuntes sobre las composiciones de tierras en la Nueva España", Historica 24, Praga: Academia, 1984, pp. 187-240.

"Una conferencia de iberoamericanistas en Praga (noviembre de 1991)", Ibero-Americana Pragensia 26, Praga: Editorial Karolinum, 1992, pp. 287-288.

"Počátky a předpoklady fašismu ve Španělsku", in: Sborník k problematice dějin imperialisти 18, Praha: Ústav československých a světových dějin ČSAV, 1985, pp. 57-239.

"La idea y la práctica del fomento de la población blanca en Cuba en la primera mitad del siglo XIX", Revista Universitaria de Historia 9, Caracas: Universidad de Santa María, 19851986-1987, pp. 41-70.

“Antifašistické hnutí ve Španělsku”, in: Karel Herman et al., Boj evropských národì protifašismu v letech 1933-1945, Praha: Academia 1988, pp. 108-136.

"Konference o zrušení otroctví na Kubě", Latinská Amerika. Dějiny a současnost 1, Praha: Orientální ústav ČSAV, 1988, pp. 232-236.

"Mezinárodní kolokvium Výboru historiků Španělska - NDR v Lipsku", Latinská Amerika. Dějiny a současnost 1, Praha: orientální ústav ČSAV, 1988, pp. 249-252.

"Los Cchecoslovacos en Argentina durante la Primera Guerra Mundial", Ibero-Americana Pragensia 23/1989, Praga: Editorial Karolinum, 1999, pp. 213-237.

"Kolokvium o alternativách sociálního vývoje v Latinské Americe v Rostocku", Latinská
Amerika. Dějiny a současnost, Praha: Orientální ústav ČSAV, 1989, vol. 2, pp. 311-317.

"El Corazón de Europa y el Nuevo Mundo", $17^{\circ}$ Congreso International de Ciencias Históricas. I., II / $17^{\mathrm{e}}$ Congrés International des Sciences Historiques I., II, Madrid: Comité Español de Ciencias Históricas 1990, pp. 20-21.

"Ze XVII. mezinárodního kongresu historických věd", Folia Historica Bohemica 14, Praha: Historický ústav AV ČR, 1990, pp. 539-546.

“17. mezinárodní kongres historických věd v Madridu", Český časopis historický 89/2, Praha: Nakladatelství Akademie věd České republiky (en adelante sólo AV ČR), 1991, pp. 306-312.

"Hispanica e hispanoamericana de los siglos XVI y XVII en los archivos de Bohemia y Moravia”, Ibero-Americana Pragensia 26, Praga: Editorial Karolinum, 1992, pp. 195-215.

"Španělsko Katolických králů”, Dějiny a současnost 14/5, Praha: Nakladatelství Lidových novin, 1992, pp. 19-25.

"Styky mezi Českým královstvím a Španělskem ve středověku", Táborskýarchiv 7, Tábor: Státní okresní archiv Tábor, 1995-1996, pp. 5-87.

Con Monika BAĎUROVÁ, "Vystěhovalectví z českých zemí do Brazílie před vznikem ČSR", Český lid 82/4, Praha Academia, 1995 , pp. 323-335

"La isla de Tenerife en los viajes y en la vida de Enrique Stanko Vráz", XII Coloquio de Historia Canario-Americana, Gran Canaria: Ediciones del Cabildo Insular 1996, pp. 649-661.

"Ditrichštejnové a Španělsko", in: Ivo Barteček - Jaroslav Reska (eds.), České země a Španělsko, Ostrava: Filozofická fakulta Ostravské univerzity 1996, pp. 41-58.

"Josef Polišenský", Zpravodaj Historického klubu 7/2, Praha, Historický klub-Sdružení českých, moravských a slezských historiků, 1996, pp. 44-45.

"A emigração dos países tchecos ao Brasil antes de originar-se a República Tchecoslovaca", con Monika BAĎUROVÁ, Ibero-Americana Pragensia 31, Praga: Editorial Karolinum, 1997, pp. 41-67.

"La Casa de Dietrichstein y España", Ibero-Americana Pragensia 33, Praga: Editorial Karolinum, 1999, pp. 47-67.

"Apuntes sobre las composiciones de tierras en la Nueva España", Novahispania 5, 2000, pp. 5-86. 
"Kardinál Dietrichstein a Martyrologium z Gerony", con Josef Polišenský Jižní Morava 36, Brno: Muzejní a vlastivědná společnost, 2000, vol. 39, pp. 253-254.

"El caso de algunos ex-misioneros jesuitas: las gestiones para su liberación", in: Manfred Tietz (ed.), Los jesitas expulsos. Su imagen y su contribución al saber sobre el mundo hispánico en la Europa del siglo XVIII, Madrid - Frankfurt am Main: Iberoamericana - Vervuert 2001, pp. 133-168.

"Josef Polišenský, una cumbre de la historiografía checa. In memoriam (16.12.1915 Prostějov-11. 1. 2001 Praga)", Ibero-Americana Pragensia 35/2001, Praga: Editorial Karolinum, 2002, pp. 9-16.

"Sátira contra El Escorial: Comparación de tres manuscritos", Ibero-Americana Pragensia 35/2001, Praga: Editorial Karolinum, 2002, pp. 77-94.

"Alžír nebo Čechy? Španělské dilema”, Český časopis historický 100/3, 2002, pp. 586-628.

"Vicisitudes de vida de un esclavo cubano", Ibero-Americana Pragensia 38/2004, Praga: Editorial Karolinum, 2005, pp. 129-134.

"Markýza de Mondéjar", Jižní Morava 40, Brno: Muzejní a vlastivědná společnost, 2004, vol. 43, pp. 81-108.

"Markýza de Mondéjar. [Parte] II", Jižní Morava 41, Brno: Muzejní a vlastivědná společnost, 2005, vol. 44, pp. 59-82.

"Los Borja y el Reino de Bohemia", Ibero-Americana Pragensia 39/2005, Praga: Editorial Karolinum, 2006, pp. 43-72.

"K počátkům obchodu se sklem mezi Čechami a Mexikem", in: Porta Bohemica. Sborník historických prací 3, Ústí nad Labem: Artis International, 2005, pp. 120-194.

"Epílogo de las relaciones entre la compañía Hiecke, Rautenstrauch, Zincke y Tadeo Haenke", in: Josef Opatrný (ed.), La expedición de Alejandro Malaspina y Tadeo Haenke (=Ibero-Americana Pragensia, Supplementum 14), Praga: Editorial Karolinum 2005, pp. 125-129.

"Documenti ignoti sui comici italiani della terza decade del seicento", Folia Historica Bohemica 21, Praha: Historický ústav AV ČR, 2005, pp. 211-218.

"Poznámky k řádu točenice”, Heraldika a genealogie 39/3-4, Jílové u Prahy: Česká heraldická a genealogická společnost při Okresním muzeu Praha-Západ, 2006, pp. 273-274.
"Los intereses económicos de los Dietrichstein y España", in: Josef Opatrný (ed.), Las relaciones checo-españolas (=Ibero-Americana Pragensia, Supplementum 20), Praga: Editorial Karolinum 2007, pp. 47-92.

"Dampierrova první zpráva o bitvě u Věstonic", Jižní Morava 43, Brno: Muzejní a vlastivědná společnost, 2007, vol. 46, pp. 213-221.

"Josef Polišenský - iberoamerikanista", in: Tomoko Asomura - Ivo Barteček - Zdeněk Šamberga (eds.), Ad honorem Josef Polišenský (1915-2001), Olomouc: Univerzita Palackého, Filozofická fakulta, 2007, pp. 29-57.

"IV Simposio Internacional La emigración centroeuropa a América Latina. Emigración en testimonios y novelas (Praga, 26 al 27-VII2006)", Ibero-Americana Pragensia 40/2006, Praga: Editorial Karolinum, 2008, pp. 257-259.

"Hospodářské zájmy Ditrichštejnů ve Španělsku v 16.-18. stoletî", Jižní Morava 46, Brno: Muzejní a vlastivědná společnost, 2010, vol. 49, pp. 55-100.

"¿Argel o Bohemia? El dilema español (16181619): $1^{a}$ parte", Ibero-Americana Pragensia 45/2010, Praga: Editorial Karolinum 2016, pp. 43-65; $2^{\mathrm{a}}$ parte, Ibero-Americana Pragensia 44/1, Praga: Editorial Karolinum, 2017, pp. 27-71.

\section{Notas y reseñas}

"Falešný obraz Bílé Hory /recenze práce B. Chudoby/", con Josef Polišenský, Československý časopis historický 3/4, Praha: Nakladatelství ČSAV, 1955, pp. 674-679.

"Nové práce $\mathrm{k}$ dějinám objevných cest a $\mathrm{k}$ počátkům kolonialismu", Československý časopis historický 4/3, Praha: Nakladatelství, ČSAV, 1956, pp. 524-529.

"William Hickling Prescott, Dějiny dobytí Mexika, trad. Libuše Vokrová-Ambrosová, introd. Čestmír Loukotka-Otakar Nahodil, Praha: Orbis, 1956, 584 pp.”, Československý časopis historický 5/4, Praha: Nakladatelství ČSAV, 1957, pp. 795-796.

"Francisco Gamboa, Costa Rica. Monografía económico-social, La Habana, 1963, 271 pp., (Enciclopedia Popular 22)", Československý časopis historický 12, Praha: Nakladatelství ČSAV, 1964, pp. 78-80.

"Bibliografía de Centroamérica y del Caribe, Argentina y Venezuela, 1959, Edición realizada bajo el cuidado de la Comisión Nacional Cubana de la UNESCO”, Československý 
časopis historický 12/2, Praha: Nakladatelství ČSAV, 1964, p. 287.

"Arthur P.Whitaker, Nationalism in Latin America. Gainesville, 1962,91 pp.”, Československý časopis historický 12/5, Praha: Nakladatelství ČSAV, 1964, pp. 761-762.

"Dvě syntézy amerických dějin”, Československý časopis historický 12/6, Praha: Nakladatelství ČSAV, 1964, pp. 884-888.

"Bibliografia Americanista Española 1935-1963, Sevilla, 1964, 565 pp.”, Československý časopis historický 13/1, Praha: Nakladatelství ČSAV, 1965, pp. 123-124.

"Sherburne F. Cook - Woodrow Borah, Essays in Population History, Mexico and the Caribbean, vol. I, Berkeley - Los Angeles - London, University of California Press, 1971, 14 il. + 455 pp.”, Československý časopis historický 20/6, Praha: Nakladatelství ČSAV, 1972, pp. 929-930.

"Jorge Ibarra, Algunos problemas teóricos y metodológicos de la historiografia cubana, Santiago, Revista de la Universidad de Oriente, 1971, pp. 185-193”, Československý časopis historický 20/6, Praha: Nakladatelství ČSAV, 1972, pp. 952-953.

"Miguel Izard, El comercio venezolano en una época de transición: 1777-1830, in: Miscellanea Barcinonensia, Barcelona, 1971, pp. 7-44," Československý časopis historický 22/1, Praha: Nakladatelství ČSAV, 1974, pp. 129-130.

"Peter Gerhard, A Guide to Historical Geography of New Spain, Cambridge UP, 1972, 476 pp., (Cambridge Latin American Studies 14)", Československý časopis historický 22/6, Praha: Nakladatelství ČSAV, 1974, pp. 909-910.

"Alfred W. Crosby, Jr., The Columbian Exchange. Biological and Cultural Consequences of 1492, Westport (Connecticut), Greenwood Publishing Company, 1972, 268 pp. (Contribution in American Studies 2)", Československý časopis historický 22/6, Praha: Nakladatelství ČSAV, 1974, pp. 910-911.

"Emilia Salvador, La economía valenciana en el siglo XVI, (Comercio de importación), Valencia, Universidad de Valencia, 1972, 408 pp.”, Československý časopis historický 23/1, Praha: Nakladatelství ČSAV, 1975, pp. 130-131.

"Ernesto de la Torre Villar, Fray Pedro de Gante, Maestro y civilizador de América, México, Seminario de Cultura Mexicana, 1973, 143 pp.”,
Československý časopis historický 23/3, Praha: Nakladatelství ČSAV, 1975, p. 430.

"George C. Vaillant, Aztékové. Původ, vzestup a pád národa Aztéků, Praha, Orbis, 1974, 257 pp.”, Československý časopis historický 23/4, Praha: Nakladatelství ČSAV, 1975, p. 606.

"Josef Opatrný, Benito Juárez, Praha, Horizont 1974, 95 pp.”, Československý časopis historický 23/4, Praha: Nakladatelství ČSAV, 1975 , p. 609 .

"Kolonialismus, imperialismus a fašismus v ibero-americkém světě, Praha, Universita Karlova, 1973, 227 pp., (Acta Universitatis Carolinae. Philosophica et Historica 3-4, Studia Historica 9-10.)", Československý časopis historický 23/4, Praha: Nakladatelství ČSAV, 1975, pp. 627-628.

"Jan Kovanda, Latinská Amerika-kontinent v pohybu, Praha, Svoboda, 1976, 437 pp.”, Československý časopis historický 25/4, Praha: Nakladatelství ČSAV, 1977, pp. 630-631.

"Josep Fontana, La crisis del Antiguo régimen 1808-1833, Barcelona, Editorial Crítica, 1979, 290 pp., (Guías de historia contemporánea de España 1)", Československý časopis historický 28/3, Praha: Nakladatelství ČSAV, 1980, pp. 456-457.

"Magnus Mörner, Perfil de la sociedad rural del Cuzco a fines de la colonia, Lima, Universidad del Pacífico, 1978, 187 pp.”, Československý časopis historický 28/4, Praha: Nakladatelství ČSAV, 1980, p. 615.

"Magnus Mörner, Evolución demográfica de Hispanoamérica durante el período colonial. Stockholm, Institute of Latin America Studies, 1979, 77 pp.", Československý časopis historický 28/4, Praha: Nakladatelství ČSAV, 1980 , p. 615.

"Hans Kaufmann, Maurové a Evropa. Cesty arabské vědy a kultury, Praha, Panorama, 1982 , 182 pp.," Československý časopis historický 31/2, Praha: Nakladatelství ČSAV, 1983, pp. 285-286.

"Spis o nových zemích a o novém světě. Faksimilie a výklad plzeňského tisku Mikuláše Bakaláře z roku 1506, ed. Pravoslav Kneidl, Praha, Památník národního písemnictví, 1981, 189 pp. + il," Československýčasopis historický31/3,Praha: Nakladatelství ČSAV, 1983, pp. 438-439.

“Oldřich Kašpar, Nový Svět v české a evropské literatuře 16.-19. století, Praha, Univerzita Karlova, 1983, 122 pp. + 31 il., (Acta Universitatis 
Carolinae. Philosophica et historica 1980. Monographia 84)", Československý časopis historický 32/2, Praha: Nakladatelství ČSAV, 1984, p. 285.

"Guida agli archivi della Resistenza a cura della Commissione Archivi-Biblioteca dell' Instituto nazionale per la storia del movimento di liberazione in Italia, (Publicazioni degli Archivi di Stato. Strumenti IC.)", Československý časopis historický 33/1, Praha: Nakladatelství ČSAV, 1985, pp. 151-152.

"Miriam Halpern Pereira, Política y economía. Portugal en los siglos XIX y XX, Barcelona, Editorial Ariel, 1984, 204 pp.”, Československý časopis historický 33/2, Praha: Nakladatelství ČSAV, 1985, pp. 282-283.

"Laird W. Bergad, Coffee and the Growth of Agrarian Capitalism in Nineteenth-Century Puerto Rico, Princeston, N.Y., University Press, 1983, 242 pp.”, Československý časopis historický 33/3, Praha: Nakladatelství ČSAV, 1985, pp. 442-443.

“Aurora Bosch Sánchez, Ugetistas y libartarios. Guerra civil y Revolución en el París Valenciano, 1936-1939, Valencia, Institución Alfonso el Magnánimo, Diputación Provincial de Valencia, 1983, 402 pp.”, Československý časopis historický 33/3, Praha: Nakladatelství ČSAV, 1985, pp. 449-450.

"Pablo Iglesias, Escritos y discursos. Antología crítica., ed. Enrique Moral Sandoval, Santiago de Compostela, Ediciones Sálvora, 1984, 661 pp.”, Československý časopis historický 35/6, Praha: Nakladatelství ČSAV, 1987, pp. 916-917.

"Z nejnovějších prací k diktatuře Prima de Rivery", in: Sborník k problematice dějin imperialismu 23, Praha: Ústav československých a světových dějin ČSAV, 1988, pp. 197-221.

"Josef Opatrný, Antecedentes históricos de la formación de la nación cubana, Praha, Universidad Carolina, 1986, 254 pp., (=Ibero-Americana Pragensia, Supplementum 3, 1984)," Československý časopis historický 36/2, Praha: Nakladatelství ČSAV, 1988, pp. 255-258.

"Bohumír Roedl, Ve jménu inky Túpaka Amarua, Praha, Scriptorium, 1998, 352 pp., il., mp.", Český časopis historický 97/4, Praha: Nakladatelství ČSAV, 1999, pp. 836-838.
"Jan Filipský et al., Čeští a slovenští orientalisté, afrikanisté a iberoamerikanisté, Praha, Libri, 1999, 620 pp., il. (Kdo byl kdo)", Ibero-Americana Pragensia 33, Praga: Editorial Karolinum, 1999, pp. 244-245.

"Josef Opatrný, Kuba, Praha, Libri 2002. 100 pp. (Stručná historie států 1)", Český časopis historický 100/3, Praha: Nakladatelství ČSAV, 2002, p. 660.

"Josef Opatrný, Mexiko, Praha, Libri 2003, 212 pp. (Stručná historie států 14)”, Ibero-Americana Pragensia 37, Praga: Editorial Karolinum, 2003 (2004), pp. 213-214.

"Josef Opatrný (ed.), Cambios y revoluciones en el Caribe hispano de los siglos 19 y 20 , Praha, Editorial Karolinum 2003, 296 pp., (=Ibero-Americana Pragensia, Supplementum 11, 2003)", Český časopis historický 102/4, Praha: Nakladatelství ČSAV, 2004, pp. 861-863.

"Milada Bažant - Jan Jakub Bažant (eds.), Diario de un soldado. Josef Mucha en México, 18641867, México, Miguel Angel Porrúa Grupo Editorial, 2004, 149 pp.”, Český časopis historický 103/4, Praha: Nakladatelství ČSAV, 2005, pp. 955-956.

"Josef Opatrný (ed.), Emigración centroeuropea a América Latina III, Praha, Editorial Karolinum, 2005, 175 pp., (Ibero-Americana Pragensia, Supplementum 13, 2005)", Český časopis historický 104/1, Praha: Nakladatelství ČSAV, 2006, pp. 147-149; Ibero-Americana Pragensia 39/2005, Praga: Editorial Karolinum, 2006, pp. 245-246.

"Josef Opatrný (ed.), Emigración centroeuropea a América Latina IV. Emigración en testimonios y novelas, Praga, Editorial Karolinum, 2006, 189 pp., (Ibero-Americana Pragensia, Supplementum 17, 2006)", Český časopis historický 105/4, Nakladatelství ČSAV, 2007, pp. 962-964.

"Bohumír Roedl, Araukánské války 1546-1681, Španělské Flandry v Chile, Praha, Scriptorium, 2007, 356 pp.”, Český časopis historický 106/2, Nakladatelství ČSAV, 2008, pp. 439-440; Ibero-Americana Pragensia 41/2007, Praga: Editorial Karolinum, 2009, pp. 277-280. 